Eurasia: Economics \& Business, 2(20), February 2019

DOI https://doi.org/10.18551/econeurasia.2019-02

UDC 332

\title{
THE EFFECT OF DESTINATION IMAGE, MARKETING COMMUNICATION, AND TOURIST EXPECTATION TO TOURIST LOYALITY IN PAGAR ALAM CITY, INDONESIA
}

\author{
Elvera* \\ STIE Lembah Dempo Pagar Alam, Indonesia \\ Bernadette Robiani, Taufiq Marwa, Zakaria Wahab \\ University of Sriwijaya, Palembang, Indonesia \\ *E-mail: elvera.star@gmail.com
}

\begin{abstract}
The purpose of this present research is to examine and analyze the influence of destination image, marketing communication, and tourist expectation on tourist satisfaction and loyalty in Pagar Alam City, Indonesia. The population of this research was taken from the 2017 tourist database with the total number of 224,103 people. An accidental sampling was done in order to obtain 399 samples of the population. To collect the data, a survey was conducted to the domestic and foreign tourists visiting some destinations which currently become the main tourist attractions, namely Mount Dempo, Curup Mangkok Waterfall, Dempo Park, and Batu Megalit Tourism. The analysis technique employed in this research was the structural equation model (SEM) approach using the AMOS program package. The results showed that the marketing communication and the satisfaction were factors that proved to be significant in increasing the tourist loyalty directly, while the destination image and the tourist expectation could only influence the tourist loyalty through the satisfaction variable. These results indicate that the destination image and the tourist expectation can contribute significantly to the increase of tourist loyalty as long as the tourist expectations are implemented into the tourist satisfaction.
\end{abstract}

\section{KEY WORDS}

Satisfaction, loyalty, destination image, marketing communication, tourist expectation.

Tourism is a potential resource. In maximizing its potential various strategies need to be taken in order to provide satisfaction and loyalty for tourists. Gramer and Brown (2006) provide a definition of loyalty (service loyalty), namely the degree to which a consumer shows repeat buying behavior from a service provider, has a disposition or positive attitude toward the service provider, and considers to use only this service provider when he needs to use the service. From its definition, loyal consumers are not only buyers who make repeat purchases, but also maintain a positive attitude towards service providers.

In Aaker (2004), one of the influencing factors on consumer loyalty is satisfaction. Consumers will be loyal to a product if they get satisfaction from the product. Therefore, the consumers may try several kinds of products whether the products are beyond the product satisfaction criteria or not. If after trying the consumers' responds are well, it means that the consumers are satisfied then they will decide to buy the products consistently throughout time. In other words, this consumer loyalty has been created for the products. In the context of tourism, satisfaction with travel experiences contributes to loyalty (Alexandris, Kouthouris, \& Meligdis, 2006; Bramwell, 1998; Pritchard \& howard, 1997). The level of tourist loyalty in a tourist destination is reflected in their intention to revisit and their willingness to recommend the destination to others (Oppermann, 2000). Another point of view revealed by Marconi (1993) that states the influencing factor on product or service that can also create loyalty is the Image. Image is in the context of tourism according to Artuğer, Cetinsoz, and Kılıc (2013). The first study to discuss the concept of image in tourism was realized in the early 1970s (Stepchenkova \& Morrison, 2008). Analysis and assessment of destination image is important in understanding tourist behavior. Many studies have revealed that destination 
image plays a major role in the selection of destinations (Beerli \& Martin, 2004). Dadgostar and Isotalo (1992) define destination image as the impression and attitude of a person towards a place. Another definition pointed out is that destination image as the image of the perceived destination that holds a significant place in terms of market competitiveness (Martin \& del Bosque, 2008). Various studies that examine destination image and loyalty variables have been carried out by Artuğer, Cetinsoz, and Kılıc (2013) and they showed a significant relationship and a significant positive influence of destination image on loyalty. Furthermore, Mohamad, Ali, Ghani (2014) revealed that destination image has a significantly positive effect on the intention of tourists to return.

In addition to building the destination image well, tourism must be able to communicate every destination owned by both foreign and domestic tourists in achieving satisfaction and loyalty. McCabe (2009) states that tourism has intangible characteristic as it is impossible to show before the demand for services is done. Considering the difficulty of communicating tourism in marketing, Mittal and Baker (2002) conclude the four key challenges in tourism marketing communication, namely: 1) abstractness: the difficulty of communicating because it is different from the concept of services in general; 2) generality: the difficulty of demonstrating the superiority of an offered service in general; 3) non searchability: the difficulty of carrying out preliminary evidence such as tasting the taste of a food or beverage; and 4) impalpability: the needs of deep understanding and interpretation before conducting marketing communication.

Several research studies have been conducted to analyze the general impact of marketing communications in the tourism sector. Some of them were conducted by Schellhom and Perkins (2004), Yuksel and Akgul (2007), and Mittal and Baker (2002) who found how difficult it is to communicate tourism in marketing. Competition between destinations will also affect management and marketing communications, thus all information must reflect the brand. Effective marketing communication is expected to be able to bring up tourist expectations of the attractions visited. Lather et al. (2012: 5) states that tourist expectation is about the level of expectation and satisfaction that has the important meaning of sustainable tourism development in the destination image of a tourist destination. Tourist expectation is also delineated by Ismayanti (2010: 68) as a service whose series of activities designed to fulfill the tourist satisfaction, where the product or service has achieved the desired expectations.

According to Robert Mc. Intosh and Shaskinant Gupta in Yoeti (1992: 8) tourism is a combination of symptoms of relationships arising from tourist interactions, businesses, host governments and host communities in the process of attracting and serving tourists and other visitors. Indonesia is famous for its beautiful natural charm, diverse and unique culture, distinctive food, and a wealth of other attractions as assets for Indonesian tourism. This is what makes Indonesia the right choice for foreign tourists when traveling. South Sumatra is one of the provinces in Indonesia that has tourism assets. One of the leading destinations in South Sumatra is Pagar Alam City. In 2015, 50 percent of tourists, both domestic and foreign, wanted natural tourist areas. This big opportunity is owned by Pagar Alam City.

In reference to the Indonesia's Statistics Center (BPS) Pagar Alam data (2017), the number of foreign tourists visiting Pagar Alam City in 2016 was 102 people. This number had increased by 26 percent compared to 2015 , and get fluctuated every year. As a comparison, the domestic tourists were almost 300 percent larger than the foreign tourists. In 2016, there were 126,364 tourists visiting Indonesia and this number continued to increase from the previous two years. The following is a graph that illustrates the number of foreign and domestic tourists coming to Pagar Alam City.

Based on these data, the phenomenon that should be focused on is the relatively low number of foreign tourist who visit in comparison with the domestic tourists. The unideal number of tourists expected then become one issue when it is not comparable to the charm of tourist destinations in Pagar Alam. Attractions in Pagar Alam consist of both natural and cultural attractions. Besides being famous for its natural beauty, Pagar Alam City is also rich in historical heritage. Numerous waterfalls and megalithic rocks are found in Pagar Alam. At least there are 15 natural tourist attractions and 25 cultural tourism places. These natural 
attractions are Mount Dempo, bamboo forest, and so on, while the cultural tourism objects are traditional house Besemah, historical stones, monuments, statues, and so on (Pagar Alam Dalam Angka, 2017). This is what makes Pagar Alam a favorite destination in South Sumatra. One effort to increase the visits of domestic and foreign tourists by various parties in general and the government is by increasing the destination image and the need for improving ideal and good tourism marketing communications in Pagar Alam City. With good expectation from the tourists, the tourist satisfaction and loyalty will be created.

\section{LITERATURE REVIEW}

Griffin (2003) provides a definition of loyalty that is "when a customer is loyal, he or she exhibits purchase behavior defined as non-random purchase expressed over time by some decision-making units". According to Kotler and Keller (2006), indicators of customer loyalty are repeat purchase (loyalty to product purchase); retention (resistance to negative influences about the company); referalls (referring in total to the company's existence). Further in Griffin (1995), 4 attributes of loyalty are explained, namely: a. Make regular repeat purchase; b. Purchase across product and service line; c. Refer others; $d$. Demonstrate immunity to the pull of the competition.

There are various meanings given by the experts to describe satisfaction (Tjiptono, 2012). Day in Tse and Wilton (1988) explains that customer satisfaction is the customer's response to the evaluation of perceived nonconformities between previous expectation (or other performance norms) and the actual performance of the product which is experienced after its use. According to Gaspersz (2005), the factors that influence customer satisfaction and expectation consist of "needs and desires" relating to the things that the customer feels when he is trying to make a transaction with a service producer. In conceptual, Chi and Qu (2008) reveal seven dimensions of satisfaction in traveling, namely: shopping, activities and events, lodging, accessibility, attraction, environment, and food.

According to Pitana and Diarta (2009), destination image is a trust held by tourists regarding products or services that they buy or will buy. Destination image is not always formed from experiences or facts, but also can be created that it can become a strong motivating factor for tourists to have a tourist destination. Chi and Qu (2008) reveal the nine dimensions of destination image namely: travel environment, natural attraction, entertainment and events, historical attraction, travel infrastructure, accessibility, relaxation, outdoor activities, prices and costs.

Kotler and Keller (2008) state that marketing communication is a means by which companies try to inform, persuade and remind consumers directly or indirectly about the products and brands sold. According to Lovelock and Wirtz (2004) marketing communications for services include: (1) personal communications, are personal selling activities, customer service, training, telemarketing, and word of mouth communication; (2) advertising, is an activity that includes broadcasts, prints, internet, outdoor media, and direct mail; (3) sales promotions, are activities related to product samples, coupons, merchandise, price discounts, and promotions in the form of special prices; (4) publicity and public relations, are activities that include press release/kits, press conferences, special events, and sponsorships; (5) instructional materials, including websites, manuals, brochures, video/audio cassettes, and voice mail; and (6) corporate design, including interior decoration, vehicles, equipment, and uniforms.

Oliver (1997) declares that expectation is the anticipation of future consequences based on the main experience, current situation, or other sources of information. Based on Horovitz (2000) expectation can be formed by 4 factors, including: 1. similar experience, 2. price paid, 3. past experience expectations, and 4. communications by the service provider (Horovitz, 2000, p. 8.). Tourist expectation is an important factor in tourist destinations and activities. Bosque and Martin (2008) argue that views influence expectation. A good expectation for a tourist destination will have a positive impact on the confidence of tourists to visit and look for tourist destination experiences. Further, Akama and Kieti (2003) explain 
that expectation is formed through information provided in the form of advertising, brochures, mass media, friends or relations.

\section{METHODS OF RESEARCH}

The research design was explanatory research, in which this research analyzed the causal relationship between destination image, marketing communication, tourist expectation, tourist satisfaction and loyalty in Pagar Alam City through a survey method. The data collection was done by using a survey to the research respondents, namely domestic and foreign tourists visiting the currently main tourist destinations. These tourist destinations were Mount Dempo, Curup Mangkok Waterfall, Dempo Park, Batu Megalit Tourism. The population of this research was from the 2017 tourist database which had the total number of 224,103 tourists. Then the sampling was taken using Accidental Sampling technique. Of the total population, 399 samples were obtained who were represented by 9 foreign tourists and 390 domestic tourists. The analysis technique employed in this research was the structural equation model (SEM) approach using the AMOS program package.

\section{RESULTS AND DISCUSSION}

The data analysis employed in this quantitative research was Structural Equation Modeling (SEM) by first testing the variables through confirmatory factor analysis. The SEM model also analyzed to obtain and to evaluate the suitability of the proposed model.

After knowing all the results of data processing, then the results were discussed and lastly the conclusions were drawn based on the results of data analysis. After the quantitative research proved the hypothesis then in this section the results of this research are presented to prove, deepen, expand, weaken or abort the quantitative data that has been obtained. Finally, at the end of this section, the Model of Tourist Loyalty in Pagar Alam City is formulated.

The results of the CFA final model formation for Destination Image variable obtain the loading factor values for all indicators that are greater than 0.5 and the reliability values of Destination Image variable are explained in Table 1.

Table 1 - The Normality Test Results of All Variables

\begin{tabular}{|c|c|c|c|c|c|c|}
\hline Variable & Min & Max & Skew & c.r & Kurtosis & c.r \\
\hline$Z 6$ & 6 & 30 & -0.113 & -0.884 & -0.462 & -1.809 \\
\hline Z5 & 3 & 15 & -0.088 & -0.689 & -0.465 & -1.822 \\
\hline Z4 & 2 & 10 & -0.193 & -1.512 & -0.277 & -1.085 \\
\hline Z3 & 2 & 10 & -0.265 & -2.075 & -0.496 & -1.944 \\
\hline Z2 & 2 & 10 & -0.028 & -0.221 & -0.405 & -1.586 \\
\hline Z1 & 3 & 15 & 0.011 & 0.088 & -0.654 & -2.56 \\
\hline Y4 & 3 & 15 & -0.039 & -0.309 & -0.801 & -3.137 \\
\hline Y3 & 5 & 25 & -0.105 & -0.822 & -0.715 & -2.8 \\
\hline Y2 & 4 & 20 & -0.204 & -1.594 & -0.671 & -2.629 \\
\hline $\mathrm{Y} 1$ & 6 & 30 & -0.209 & -1.639 & -0.293 & -1.146 \\
\hline X3.1 & 2 & 10 & -0.056 & -0.437 & -0.845 & -3.308 \\
\hline $\mathrm{X} 3.2$ & 2 & 10 & -0.11 & -0.858 & -0.879 & $\begin{array}{l}-3.442 \\
\end{array}$ \\
\hline X3.3 & 4 & 20 & -0.081 & -0.635 & -0.824 & -3.226 \\
\hline X3.4 & 2 & 10 & -0.304 & -2.379 & -0.371 & -1.451 \\
\hline X2.1 & 2 & 10 & -0.159 & -1.249 & -0.625 & -2.448 \\
\hline $\mathrm{X} 2.2$ & 5 & 25 & 0.087 & 0.683 & -0.8 & -3.132 \\
\hline $\mathrm{X} 2.3$ & 3 & 15 & 0.146 & 1.143 & -0.619 & -2.426 \\
\hline X2.4 & 2 & 10 & 0.24 & 1.876 & -0.62 & -2.427 \\
\hline $\mathrm{X} 1.6$ & 3 & 15 & -0.063 & -0.491 & $\begin{array}{l}-0.729 \\
\end{array}$ & -2.853 \\
\hline $\mathrm{X} 1.5$ & 3 & 15 & -0.17 & -1.333 & -0.596 & -2.333 \\
\hline $\mathrm{X} 1.4$ & 2 & 10 & 0.148 & 1.158 & -0.721 & -2.825 \\
\hline $\mathrm{X} 1.3$ & 2 & 10 & -0.027 & -0.215 & -0.742 & -2.906 \\
\hline $\mathrm{X} 1.2$ & 3 & 15 & -0.085 & -0.666 & -0.685 & -2.681 \\
\hline $\mathrm{X} 1.1$ & 2 & 10 & -0.098 & -0.769 & -0.674 & -2.639 \\
\hline
\end{tabular}


In the normality test table above, the critical ratio (CR) values of the skewness and kurtosis are smaller from -2.58 to +2.58 , thus the data can be declared as normal. After declaring the data as normal, the next data processing is testing the SEM model whose results can be seen in Figure 1 below.

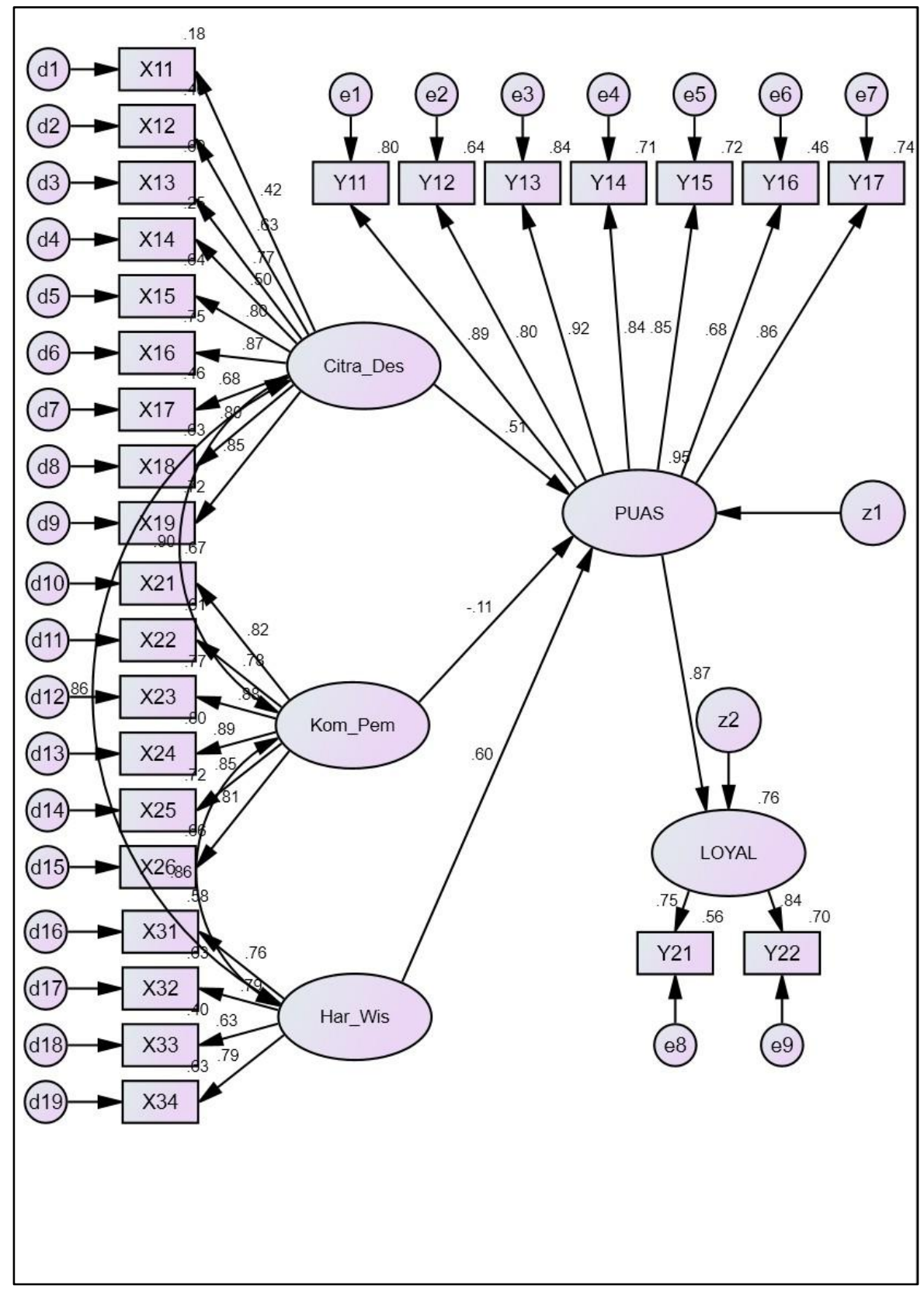

Figure 1 - The SEM Model Testing

Figure 1 above shows that the SEM model testing includes the weights of factors on the indicators which are all valid and fulfil the criteria above 0.5. This means that all the indicators to form the model that has been conceptualized are fit. However, the SEM model measurement is not only restricted to the fitness of indicators, but also to the overall measurement of model fit. Here are the evaluation results of SEM model fit displayed in Table 2.

From Table 2, it can be seen that all measurements included in the "Marginal Fit" category indicate that the value of model feasibility from the results of data processing has not met the applicable criteria in SEM. It is declared to be marginal because the value is not 
too far from the applicable numerical criteria. A number of arguments reveal that even it is still possible to accept if the number is not too far from the criteria.

Table 2 - The Evaluation Results of SEM Model Fit

\begin{tabular}{|c|c|c|c|c|}
\hline No & Fit Measurement & Cut off Value & Test Results & Descriptiom \\
\hline \multicolumn{4}{|c|}{ Absolut Fit } \\
\hline 1 & Chi Square & Expected small & 1044.126 & Marginal Fit \\
\hline 2 & GFI & $>0.90$ & 0.799 & Marginal Fit \\
\hline 3 & RMSEA & $\leq 0.08$ & 0.095 & Marginal Fit \\
\hline \multicolumn{5}{|l|}{ Incremental Fit } \\
\hline 4 & CFI & $>0.90$ & 0.765 & Marginal Fit \\
\hline 5 & TLI & $>0.90$ & 0.732 & Marginal Fit \\
\hline \multicolumn{5}{|c|}{ Parsimonious Fit Fit } \\
\hline 6 & PNFI & $>0.90$ & 0.628 & Marginal Fit \\
\hline 7 & AGFI & $>0.90$ & 0.751 & \\
\hline
\end{tabular}

The next test is a hypothesis test. The following table contains a recapitulation of the structural model test results with construction variables.

Table 3 - Recapitulation of Structural Model Test with Construction Variables

\begin{tabular}{|c|c|c|c|c|c|c|c|c|}
\hline Rel & ation & ship & Estimate & Coef. of Determination & S.E. & C.R. & $\mathrm{P}$ & Conclusion \\
\hline SATISFIED & $<--$ & Des_Image & 0.489 & \multirow{3}{*}{$94.7 \%$} & 0.071 & 6.875 & $\star \star \star$ & Significant (Ho is rejected) \\
\hline SATISFIED & $<--\mid$ & Mar_Com & -0.084 & & 0.057 & -1.468 & 0.142 & Not significant (Ho is accepted) \\
\hline SATISFIED & $<--$ & Tou_Expect & 0.524 & & 0.067 & 7.848 & 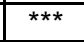 & Significant (Ho is rejected) \\
\hline LOYAL & $<---$ & SATISFIED & 0.799 & $75.6 \%$ & 0.044 & 18.248 & *** & Significant (Ho is rejected) \\
\hline
\end{tabular}

In table 3 , the values contained in the Estimation column show the regression coefficient between the two variables and are used as reference between the variables studied. The next is the Significance Value $(P)$ column showing that the $P$ Value indicates the probability or level of significance. The numbers in this column are obtained from the output Regression Weights table on the AMOS output. In the meantime, the Determination Coefficient (R2) column is to see the influence of variables simultaneously derived from the square multiple correlation table on the AMOS output.

The above structural model processing result recapitulation results in the standardized regression weight and $\mathrm{R}^{2}$ or the coefficient of determination for variables of destination image, marketing communication, and tourist expectation on loyalty with a value of $94.7 \%$. At the same time, the coefficient of determination for the satisfaction variable on loyalty is obtained as much as $75.6 \%$. This means that the model in this research is good, and the independent variables examined have been able to measure the influence on the dependent variable.

The results of data processing show that the destination image has a positive influence on the tourist satisfaction as much as 0.489 and is significant at the significance level of 0.000 , thus the hypothesis is accepted. This is supported by the results of research conducted by Coban (2012) which found that a positive destination image made the tourists felt better satisfaction. The tourists who rated positively on the destination image may be willing to visit again and recommend related destinations to other people. Mohamad, Ali, Ghani (2014) also revealed that the destination image had a significant positive effect on the intention of tourists to return. The object of this research was in Malaysia. Similarly, the research done by Artuğer, Cetinsoz, and Kılıc (2013) and Chi and Qu (2008) also found that there was a relationship and a significant positive effect of the destination image on loyalty. The results of the research by Kandampully and Suhartanto (2000) recorded the tendency of consumers to repurchase and provide recommendations with pleasant images that were trusted to guarantee high service quality. The destination image was related to a destination association which in this case was the tourist destination stakeholders in Pagar Alam City. The impression that the tourists memorized increased as more experiences of the tourists that enjoyed the destination. In conclusion, a good destination image in Pagar Alam City can 
lead to the tourist loyalty on a tour. It is important for Pagar Alam City tourism stakeholders to build the destination image to be well perceived by both domestic and foreign tourists. The new positive image can be felt by consumers after feeling satisfaction first, which in turn will form loyalty.

The marketing communication variable has a negative influence on the tourist satisfaction as low as -0.084 and is not significant $(0.142>0.05)$. Hence the hypothesis is rejected. The marketing communication variable does not contribute significantly to the increase in tourist satisfaction. This result shows that there is still a need for new concepts that can improve the relationship between marketing communication to satisfaction and tourist loyalty. Marketing communication is related to the process of forming consumer behavior and explores the interactions between consumer actions and reactions to marketing messages. The findings of this research point out that the implementation of marketing communication in the existing Pagar Alam City tourism was still less effective, thus it provided unclear information about tourist destinations. This failure of fulfilling the tourists' needs for complete information ultimately can make the tourist satisfaction unable to create.

The tourist expectation variable is the most dominant variable directly affecting the satisfaction. The tourist expectation has a positive influence on the satisfaction with a value of 0.524 and significant at 0.000 , thus the hypothesis is accepted. This corresponds to the research result conducted by Aliman et. al. (2014), which found that tourist expectation had a significant positive effect on the tourist satisfaction. This present research results are also in line with Septian and Sirait's(2014) research which also stated that tourist expectation had a significant influence on the tourist satisfaction. The tourist expectation directly influence the level of tourist satisfaction with the services received (Xia et. Al., 2009). Therefore, this tourist expectation is the first step should be taken into account by the tourism stakeholders in Pagar Alam City to attract tourists and gain experiences from existing tourist destinations.

The tourist satisfaction variable is proved to have a significant positive influence on loyalty with a large influence as much as 0.799 and is significant at 0,000 , meaning that the hypothesis is accepted. Satisfaction with travel experience contributes to the loyalty (Alexandris, Kouthouris, \& Meligdis, 2006; Bramwell, 1998; Oppermann, 2000; Pritchard \& Howard, 1997). The level of tourist loyalty in a tourist destination was reflected in their intention to return and their willingness to recommend the place to other people (Oppermann, 2000). Other studies that also support the results of this present research on the effect of satisfaction on loyalty, for examples Oliver, 1980; Cronin \& Taylor, 1992; Fornell, 1992; Anderson \& Sullivan, 1993; Tam, 2000; Bignie, Sanchez \& Sanchez, 2001; Petrick \& Backman, 2002; Chen \& Tsai, 2007; Chen, 2008; De Rojas \& Camarero, 2008. The level of domestic tourist satisfaction that visited Pagar Alam City was shown by revisiting the tourist attractions they did. Most of domestic tourists felt satisfied with the tourist destinations (Mount Dempo and Dempo Park) they visited that made them to return to the places and recommended these places to others. Similar results were also obtained from the foreign tourists. The level of satisfactions when visiting these places created loyalty which was shown by their willingness to return to Pagar Alam City.

\section{CONCLUSION}

Based on the above results of this research, there are a number of points for the conclusions as follows:

1. It is proved that satisfaction is a significantly mediating variable of the influence of exogenous variables on the endogenous one, because it has an impact on differences in the significance of the relationship compared to the direct influence. These results explain that satisfaction is a variable that is able to bridge the concept of tourist loyalty with individual ability factors such as the level of intelligence, skills, attitude, mental, and experience. In the context of this research, individual abilities are measured by Destination Image, Marketing Communication and Tourist Expectation, which has not been found in previous studies. In general, these results can be a new model in measuring Tourist Loyalty, especially in the field of marketing. 
2. The Tourist Expectation variable is the most dominant variable directly influencing the satisfaction. These result shows that tourist expectation is the first step for the tourism stakeholders in Pagar Alam City to attract tourists to come and gain experiences from the existing tourist destinations.

3. The marketing Communication variable does not contribute significantly to the increase in tourist satisfaction, while the Destination Image has the greatest indirect influence on the Satisfaction. These results indicate that a new concept is still necessary in order to improve the links between the Marketing Communication and the Image Destination with the Tourist Loyalty.

4. The Satisfaction becomes a factor that proves to be significant in increasing the Tourist Loyalty directly, while the Destination Image and the Tourist Expectation can only influence the Tourist Loyalty through the Satisfaction variable. These results indicate that the Destination Image and the Tourist Expectation can contribute significantly to the increasing Tourist Loyalty as long as the Tourist Expectation is implemented into the tourism marketing concept.

5. To increase the Tourist Loyalty in Pagar Alam City, it is necessary to have satisfaction that can be developed from the Tourist Expectation and the Destination Image.

\section{REFERENCES}

1. Aaker. (2004). Strategic Marketing Management. New York: John Wiley \& Sons, Inc.

2. Akama, J. S., \& Kieti, D. M. (2003). Measuring Tourist Satisfaction with Kenya's Wildlife Safari: a Case Study of Tsavo West National Park. International Journal of Tourism Management, 24(1), 73-81.

3. Alexandris, K., Kouthouris, C., \& Meligdis, A. (2006). Increasing Customers' Loyalty in a Skiing Resort: The Contribution of Place Attachment and Service Quality. International Journal of Contemporary Hospitality Management, 18(5), 414-425.

4. Aliman, et. al. (2014). Tourist Expectation, Perceived Quality and Destination Image: Effects on Perceived Value and Satisfaction of Tourists Visiting Langkawi Island Malaysia. Asian Journal of Business and Management, 2(3), 212-222.

5. Artuger, S., Cetinsoz, B. C., \& Kilic, I. (2013). The Effect of Destination Image on Destination Loyalty: An Application in Alanya. European Journal of Business and Management, 5(13), 124-136.

6. Beerli, A., \& Martin J. D. (2004). Factors Influencing Destination Image. Annals of Tourism Research, 313, 657-681.

7. Bigne, E. J., Sanchez, I. M., \& Sanjez, J. 2001. Tourism Image, Evaluation Variables and After Purchase Behavior: Inter-Relationship. Tourism Management, 22, 607-616.

8. Bramwell, B., \& Lane, B. (1993). Sustainable Tourism: An Evolving Global Approach.Journal of Sustainable Tourism, 1(1), 2

9. Chen, C. F., \& Dung, C. T. (2006). How Destination Image and Evaluative Factors Affect Behavioral Intentions? Tourism Management, 28(2007), 1115-1122.

10. Chi, C., \& Qu, H. (2008). Examining Structural Relationship of Destination Image, Tourist Satisfaction and Destination Loyalty: an Integrated Approach. Tourism Management, 29, 624-63.

11. Coban, Suzan. (2012). The Effects of the Image of Destination on Tourist Satisfaction and Loyalty, the Case of Copadia. European Journal of Social Sciences, 29(2), 222-232.

12. Dadgostar, B., \& Isotalo, R. M. (1992). Factors Affecting Time Spent by Near- Home Tourists in City Destinations. Journal of Travel Research, 30(3), 34-39.

13. Gaspersz, V. (2005). Total Quality Management. Jakarta: PT. Gramedia Pustaka Utama.

14. Gramer., \& Brown. (2006). Loyalitas Pelanggan sebagai Strategi Bersaing. Jakarta: Erlangga.

15. Griffin, J. (1995). Customer Loyalty: How to Earn it, How to Keep it. Singapore: Lexington Books. 
16. Griffin, J. (2003). Customer Loyalty: Menumbuhkan dan Mempertahankan Pelanggan. Jakarta: Erlangga.

17. Horovitz, J. (2000). Seven Secrets of Service Strategy. Great Britain: Prentice Hall.

18. Ismayanti. (2010). Pengantar Pariwisata. Jakarta: PT. Gramedia Widiasarana Indonesia.

19. Kandampully, J., \& Dwi, S. (2000). Customer Loyalty in The Hotel Industry: the Role of Customer Satisfaction and Image. International Journal of Contemporary Hospitality Management, 12(6), 346-351.

20. Kotler, P., \& Kevin, L. K. (2006). Manajemen Pemasaran. Jakarta: Penerbit Erlangga.

21. Lather, A. S., Singh, R., Singh, K. A. (2012). Comparing and Satisfaction of Indian and Foreign Adventure Tourist Visiting India. Applied Studies in Agribusiness and CommerceAbstract. Agroinform Publishing House, Budapest, 6(3-4), 5-14.

22. Lovelock, C., \& Wirtz, J. (2004). Service Marketing. Fifth Edition. New Jersey: Prentice Hall.

23. Marconi, Joe. 1993. Beyond Branding. Chicago: Probus Publishing Company.

24. Martin. H. S., \& Del, B. (2008). Tourist Satisfaction: A Cognitive-Affective Model. Annals of Tourism Research, 35(2), 551-573.

25. McCabe, S. (2009). Butterworth-Heinemann is an imprint of Elsevier Linacre House. UK: Jordan Hill

26. Mittal, B., \& Baker, J. (2002). Advertising strategies for hospitality services. Cornell Hotel and Restaurant Administration Quarterly, 43(2), 51-63.

27. Oliver, R. L. (1997). Satisfaction A Behavioral Perspective on the Consumer. Singapore: McGraw-Hill Education.

28. Oliver, R. L. (1980). A Cognitive Model of the Atecedents and Consequences of Satisfaction Decisions. Journal of Marketing Research, 17(10), 460-469.

29. Opperman, M. (2000). Tourism Management. Brisbane: John Willey and Sons Australia.

30. Pitana, I. G., \& I Ketut, S. D. (2009). Pengantar Ilmu Pariwisata. Yogyakarta: Penerbit Andi.

31. Pritchard, M. P., \& Howard, D. R. (1997). The Loyal Traveler: Examining a Typology of Service Patronage. Journal of Traveler Research, 35(4), 2-11.

32. Schellhorn, M., \& Perkins, H. C. (2004). The Stuff Of Which Dreams Are Made: Representations Of The South Sea In German-Language Tourist Brochures. Current Issues in Tourism, 7(2), 95-133.

33. Steochenkova, S., \& Morrison, A. M. (2008). Rusia's Destination Image Among American Pleasure Travelers: Revisiting Echtner and Ritchie. Tourism Management, 29(3), 548560.

34. Tjiptono, F., \& Gregorius Chandra. (2012). Pemasaran Strategik. Yogyakarta: Penerbit Andi.

35. Tse \& Wilton. (1988). Kepuasan Pelanggan. Klaten: PT. Indeks Kelompok Gramedia.

36. Yoeti, O. A. (1992). Pengantar Ilmu Pariwisata. Jakarta: Pradnya Paramitha.

37. Yuksel, A., \& Akgul, O. (2007). Postcards as Affective Image Makers: An Idle Agent In Destination Marketing. Tourism Management, 28(3), 714-725. 